\title{
Burial diagenesis model for the Macumber Formation on Cape Breton Island - implications for the tectonic evolution of the Windsor Group*
}

\author{
Martine M. Savard, Greg Lynch, and Francine Fallara \\ Commission Géologique du Canada, 2700 rue Einstein, Québec Division, \\ C.P. 7500, Sainte-Foy, Québec GIV 4C7, Canada \\ Date Received May 1, 1995 \\ Date Accepted October 16, 1995
}

\begin{abstract}
The Macumber Formation, a finely laminated limestone consisting of two thin units, represents a key stratigraphic marker at the base of the Visean Windsor Group. On Cape Breton Island the formation hosts numerous $\mathrm{Pb}$ $\mathrm{Zn}$ occurrences, and its upper boundary is in contact with rocks ranging in age from Visean (early Carboniferous) to Westphalian (middle Carboniferous), the origin of the stratigraphic omissions being debatable.

This first inorganic diagenesis study identifies nine post-depositional processes, including the stabilization of marine components, and evaporite and anhedral calcite precipitation. The $\delta^{18} \mathrm{O}_{\mathrm{PDB}}(-13.0$ to $2.0 \% 0),{ }^{87} \mathrm{Sr} /{ }^{86} \mathrm{Sr}$ $(0.7076$ to 0.7079$)$ and [Sr] (50 to $10000 \mathrm{ppm}$ ) of samples, including upper and basal whole-rock units and anhedral calcite cements, show two trends enveloping the entire field of data. The trends suggest that an evaporite-derived, non-radiogenic fluid and a clastic-derived radiogenic fluid mixed and interacted with the limestone sediments, in a progressively deeper burial environment. The evaporite-derived fluid mostly imprinted the top unit of the formation. The field investigations, microscope observations and geochemical results do not indicate a meteoric overprint as would be expected if an unconformity existed along the top of the formation. The burial history documented here, and the presence of fibrous calcite indicating bedding parallel shearing, support a detachment model to explain the stratigraphic omissions within the Windsor Group.
\end{abstract}

La Formation de Macumber, composée de calcaires fins en deux minces unités, représente un marqueur stratigraphique crucial à la base du Groupe de Windsor. À l'île du Cap Breton, la formation encaisse plusieurs indices $\mathrm{Pb}-\mathrm{Zn}$ et constitue la limite inférieure d'une série d'omissions stratigraphiques à l'intérieur du Groupe de Windsor, l'origine desquelles est fortement débattue.

Cette première investigation de la diagenèse inorganique place neuf processus en une succession post-dépositionnelle incluant la stabilisation des éléments marins, et la précipitation d'évaporites et de ciments calcitiques anédriques. Les $\delta^{18} \mathrm{O}_{\mathrm{PDB}}\left(-13.0\right.$ to $2.0 \%$ ), ${ }^{87} \mathrm{Sr} /{ }^{86} \mathrm{Sr}(0.7076$ to 0.7079$)$ et [Sr] (50 to $\left.10000 \mathrm{ppm}\right)$ de microéchantillons des unités inférieures et supérieures, et de ciments anédriques montrent deux tendences enveloppant l'ensemble des résultats. Ces tendences suggèrent qu'un fluide non-radiogénique, évaporitique et un fluide radiogénique dérivé de roches clastiques, auraient affecté les sédiments calcaires au cours de leur enfouissement progressif plus profond. Le fluide évaporitique aurait principalement affecté l'unité supérieure de la formation. Les données de terrain, les observation microscopiques et les résultats géochimiques n'indiquent pas l'empreinte météorique attendue si une discordance existait au sommet de la formation. L'histoire diagénétique ici documentée, ainsi que l'existence de calcite fibreuse développée le long de plans de cisaillement parallèles au litage supportent le modèle de détachement pour expliquer les omissions stratigraphiques du Groupe de Windsor.

\section{INTRODUCTION}

This paper is the first study of inorganic diagenesis in carbonate rocks of the Macumber Formation, at the base of the Visean Windsor Group (Fig. 1a). The Macumber Formation in Nova Scotia hosts numerous $\mathrm{Pb}-\mathrm{Zn}$ occurrences and has been an exploration target for base metals for over 50 years on Cape Breton Island (Hein et al., 1993). Previous diagenetic studies of the Windsor Group have focused on organic matter and have established that the thermal alteration indices of palynomorphs are commonly low ( -2 to $2+$; Utting, 1987), and that the burial depth reached on Cape Breton Island has not exceeded the oil and gas windows (Utting and Hamblin, 1991; Fowler et al., 1993; Héroux et al., 1994). Clastic rocks and shales of the underlying Horton Group are considered to be oil source rocks (Fowler et al., 1993).

Although the carbonate petrography of the formation has been studied (e.g., Schenk, 1992), the inorganic diagenesis profile has never been established even though it is required for distinguishing mineralizing fluids from background diagenetic fluids. Characterization of the diagenetic evolution of carbonates in the basin will help define new approaches for base metal exploration.

The Macumber Formation is a key regional stratigraphic marker at the base of the Windsor Group, and also acts as a lower boundary to significant stratigraphic omissions within the Windsor Group on western Cape Breton Island (Fig. 1b).

\footnotetext{
- Geological Survey of Canada Contribution Number 10095.
} 
A

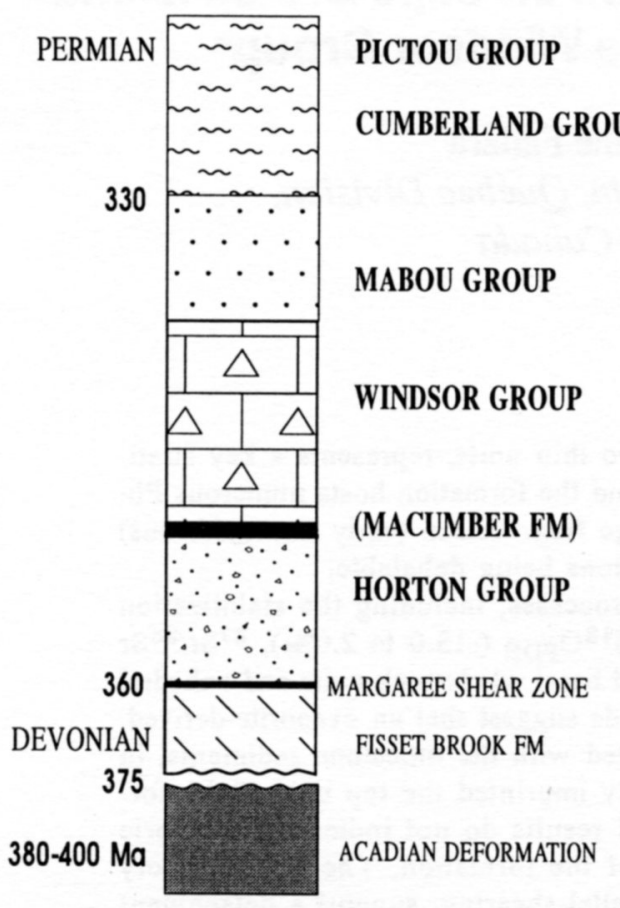

B

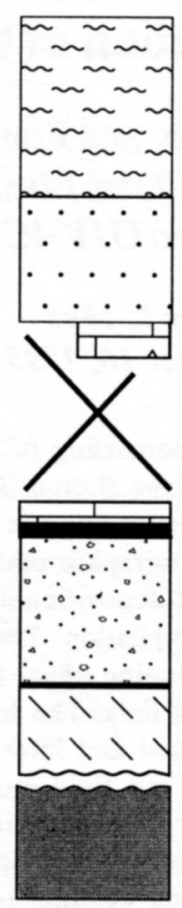

Fig. 1. (A) Stratigraphy of the studied area. The maximum thickness of the Windsor Group has been estimated at $2 \mathrm{~km}$, whereas the Macumber Formation is up to $15 \mathrm{~m}$ thick (modified from Boehner, 1986). (B) Stratigraphic column showing major stratigraphic gap, as reported by Kelley (1967) and Lynch and Giles (in press). In most areas where the gaps have been reported, clastic rocks of the Mabou Group or evaporites of the Carrolls Corner Formation directly overlie the top of the Macumber Formation.

The missing sequences are at the origin of conceptual debates about the Upper Paleozoic tectono-stratigraphic evolution of Cape Breton Island. Two explanations advocated are an unconformity caused by uplift and erosion (e.g., Kelley, 1967; Gibling et al., 1987) and a flat detachment faulting in an extensional regime (Lynch and Giles, in press; Lynch and Tremblay, 1994). Distinct diagenetic histories can be expected for each structural model: burial diagenesis should be first recorded in both cases, but followed by a meteoric imprint for the uplift/erosion model, or by shearing under shallow burial conditions in the case of the detachment model. Consequently, documenting the diagenetic evolution of the Macumber Formation may help constrain the tectono-stratigraphic evolution of the Windsor Group.

The objectives of the present paper are to document the regional diagenetic evolution of the Macumber Formation through the use of petrography and stable isotope geochemistry, to infer the nature of the fluids involved in its postdepositional history, and to discuss the implications of the diagenetic model for the tectono-stratigraphic evolution of the Windsor Group. At least nine post-depositional processes have affected the Macumber Formation. These are described here, characterized geochemically and related to their tectonic context.

\section{Methods}

Macumber Formation samples from outcrops were selected at 17 locations (Fig. 2). One hundred thin sections and corresponding blocks were stained with Red Alizarin and potassium ferricyanide, and microsampled for stable isotopes. The limestone is generally too fine grained for the separation of clasts from cements. However, late calcite cements were sampled with a Jansen drill stage from large cavity fills such as nodules and veins. Results related to the Jubilee and Sugar Camp Zn-Pb occurrences and the description of their hydrothermal systems are reported in other papers (Paradis et al., 1993; Fallara et al., 1994; Chi and Savard, 1995; Chi et al., 1995; Fallara, 1996).

The 109 carbon and oxygen isotope analyses were performed on micritic and stromatolitic limestones and late coarse anhedral calcite cements. $\mathrm{CO}_{2}$ gas was extracted by reacting $5 \mathrm{mg}$ of calcite powders for twelve hours with phosphoric acid at $25^{\circ} \mathrm{C}$. The liberated $\mathrm{CO}_{2}$ gases were analyzed on a VG-SIRA 12 mass spectrometer at the $\delta$-Lab of the Quebec Geoscience Centre, Geological Survey of Canada. The results are expressed in the usual delta notation and given in per mil (\%) relative to the Peedee Belemnite standard (PDB). All values are corrected for the presence of $17 \mathrm{O}$ and for internal linear deviation. Precision $(2 \sigma)$ of the data is $\pm 0.1 \%$.

Samples for Sr isotopic ratio were analyzed at the Geological Institute of the Ruhr University-Bochum, Germany. Eighteen powdered samples (splits from stable isotope samples), weighing from 2.0 to $4.4 \mathrm{mg}$, were dissolved in $2.5 \mathrm{~N}$ supra pure $\mathrm{HCl}$. Sr was separated by a standard ion exchange technique and loaded on a single $\mathrm{Ta}$ filament. Mass spectrometry was performed on a 5 collector FINNIGAN MAT 262 and the data normalized to ${ }^{88} \mathrm{Sr} /{ }^{86} \mathrm{Sr}$ of 8.375209 . The standards, NBS 987 and EN-1 (USGS) gave average values of 0.710193 $\pm 12( \pm 2 \sigma)$ and $0.709121 \pm 9( \pm 2 \sigma)$, respectively, in 1991, and of $0.710286 \pm 8$ and $0.709207 \pm 8( \pm 2 \sigma)$ in 1993. The $\sigma$ for single measurement was better than $2 \times 10^{-5}$. The samples analyzed in 1993 were corrected for correspondence with the 1991 ones.

\section{Geological context}

The Maritimes Basin is a large intracontinental basin featuring thick accumulations of Devonian to Permian sediments deposited during rifting and strike-slip faulting (Belt, 1968; Sheridan and Drake, 1968; Howie and Barss, 1975; Fralick and Schenk, 1981; Giles, 1981). The Macumber Formation occurs in the first of five transgressive-regressive cycles that formed the Windsor Group, the only marine interval in the Maritimes Basin (Giles, 1981). The.Windsor Group is made up of carbonates, evaporites and siltstones of Visean age, and is underlain by non-marine conglomerates, sandstones, and siltstones of the Tournaisian Horton Group. The Windsor Group is either conformably overlain by siliclastic rocks from the Namurian Mabou Group or unconformably by the 


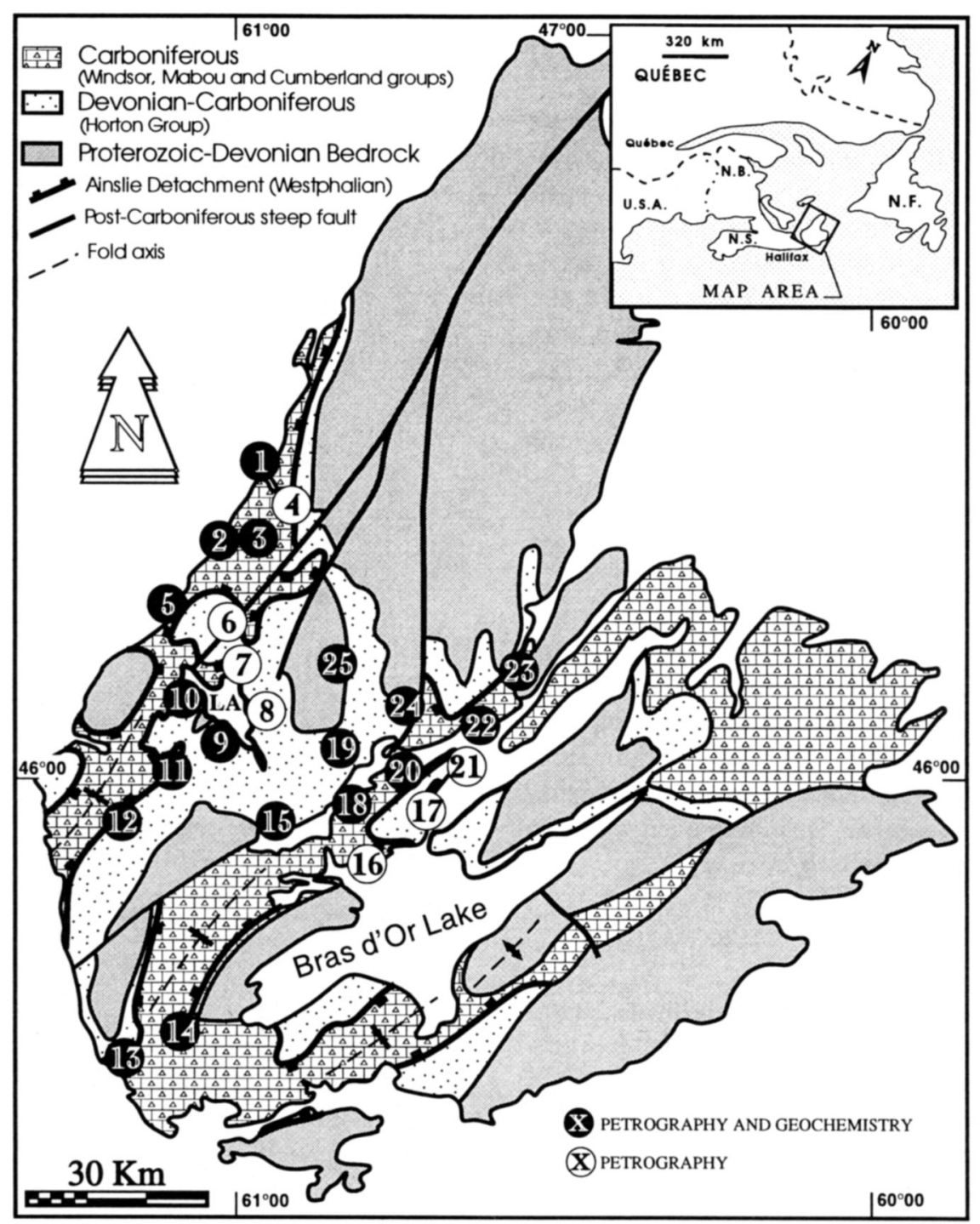

Fig. 2. Simplified map showing the geology of Cape Breton Island and the sampled locations. Mineralized sections from Jubilee and Sugar Camp (18 and 14) are not discussed in the present paper (see Chi and Savard, 1995; Fallara et al., 1994). $1=$ Margaree Harbour, 2 = Beatons Brook, 3 = Southeast Margaree, $4=$ Margaree Forks, 5 = Big Brook, $6=$ Inverness, $7=$ Upper Margaree, $8=$ East Lake Ainslie, 9 = Mount Pleasant, 10 = West Lake Ainslie, $11=$ Mabou, 12 = Meander River, $13=$ Port Hastings, $14=$ Sugar Camp, $15=$ Whycocomagh, $16=$ Red Point East, $17=$ Iona, $18=$ Jubilee and Cains Mountain, $19=$ Yankee Line, $20=$ Lower Washabuck, $21=$ John Alex Cove, $22=$ Beinn Bhreagh, $23=$ Big Bill, $24=$ Baddeck Forks and South Side Baddeck, $25=$ Upper Middle River. The distribution of the Horton Group and Carboniferous units and trace of the Ainslie Detachment are from Lynch and Giles (in press).

Westphalian Cumberland Group (Fig. 1a). At numerous studied locations, 1 to $1.5 \mathrm{~km}$ of the Windsor group is missing, and strata of the Mabou Group or of the upper Windsor Group directly overlie limestones of the Macumber Formation (Fig. 1b). These various contacts have been folded, faulted and exposed during late to post-Carboniferous Alleghenian deformation (Fig. 2).

\section{SEDIMENTOLOGY AND PETROGRAPHY}

At the locations studied, the thickness of the Macumber Formation varies between 10 and $15 \mathrm{~m}$. The formation is divided into two main lithofacies, in ascending order: (1) micritic and intramicritic bioturbated lithofacies, and (2), stromatolitic lithofacies (sometimes brecciated). These two lithofacies correspond to the strandline lithofacies A and B, respectively, of Schenk (1967), although deposition under chemosynthetic conditions (Schenk, 1992) or below fairweather wave base, under a restricted and highly saline regime (e.g., Lavoie and Savard, 1995) have been proposed.

The basal and top units consist of fine grained wackestones, packstones and bindstones characterized by overall low primary porosity and permeability. Secondary porosity as molds of evaporite nodules and fractures is very localized (under $5 \%$ where it occurs). Breccias occur at the top of the Macumber Formation at numerous locations, including Jubilee and Sugar Camp where limestone fragments of the Macumber Formation are cemented by calcite and $\mathrm{Zn}-\mathrm{Pb}$ sulfides (locations 
18 and 14, Fig. 2). The interpretation of Macumber breccia types in Nova Scotia are discussed in Lavoie et al. (1995) and Fallara (1996).

The micritic and intramicritic basal lithofacies consists of thin-bedded (10-40 cm), finely laminated, dark grey-brown limestones. For the micritic facies, the near absence of open marine fauna and wave-induced structures with, however, intense bioturbation suggest a relatively deep water environment (for a detailed description, see Lavoie, 1994 and Lavoie et al., 1995). The intramicritic facies contains a high percentage of sub-angular to rounded intraclasts (Fig. 3a), as well as oolites, peloids, and calcimicrobial clast fragments. Graded (normally and inversely) bedding suggests deposition from waning flow currents of storm origin. The micritic and the intramicritic units alternate and the transition between the two is gradational. Their total thickness is between one and ten metres.

The stromatolitic (summital) facies is dominated by flat laminites devoid of clastic sediments, sometimes containing coproliths (Fig. 3b), algal fragments and ostracods. The stromatolites (laminites) never show columnar forms, but are stratiform. In thin section (Fig. 3b), they consist of mosaics of anhedral crystals forming fine layers with a grumeleuse texture (Bathurst, 1975). Laminites are interbedded with fine grained wackestones, sometimes rich in ooids.

\section{Post-Depositional features}

Post-depositional features include recrystallization (stabilization) of metastable marine carbonates, which has produced mosaics of inclusion-rich, anhedral crystals within oolites and stromatolites (Fig. 3), and pseudosparite after micrite. The allochems are cemented by inclusion-free, anhedral calcite which fills primary pores (Fig. 4a).

In the case of the stromatolitic unit, postdepositional features also include precipitation of evaporites as nodules between laminites, or isolated crystals within laminae, later replaced by inclusion-free, anhedral calcite forming pseudomorphs after evaporites (Fig. 4b,c).

Mechanical compaction affected the coarse components of the formation, which show indented contacts due to vertical displacement prior to anhedral calcite cementation and stylolitization (Figs. 3a, 4a). Mechanical compaction formed bedding-parallel solution seams and stylolites, which are ubiquitous and post-dated the anhedral calcite cement (Figs. $3,4 a, 5)$.

Shear-related calcite fibres are found as a late feature in the upper unit. Bedding-parallel shear is indicated by the calcite fibres, which occur along slip planes or between fragmented intraclasts and peloids. Tension gashes oriented perpendicular to bedding also contain calcite fibres, indicating bedding-parallel shear as well. Some local recrystallization appears to be related to the shearing. Rotated nodules and intrafolial folds within the recrystallized laminae demonstrate a non-coaxial component to the shear. Shearing and late recrystallization crosscut solution seams and therefore must postdate chemical compaction (Fig. 5).

There is no field evidence of karsting, surficial clastic
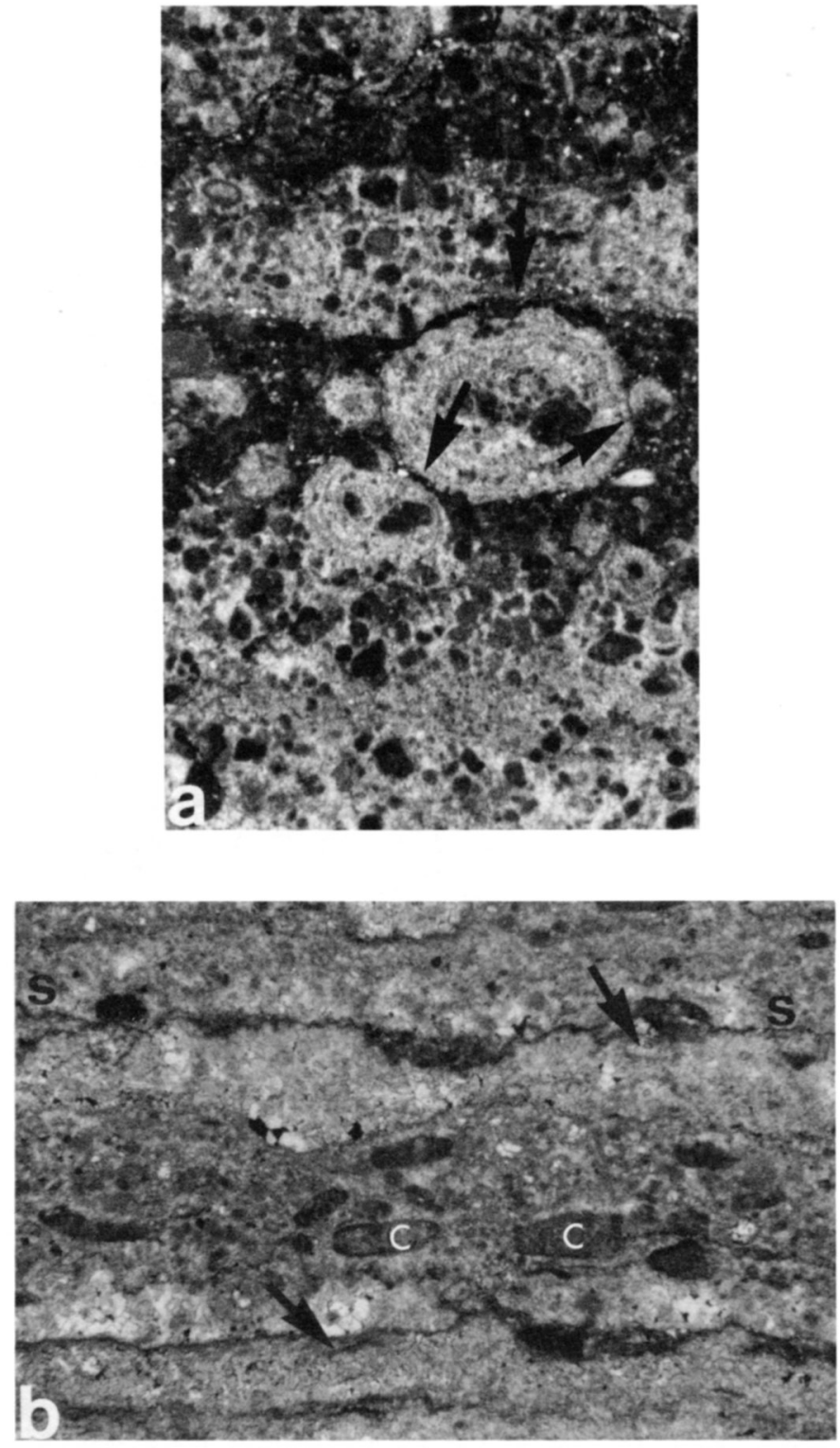

Fig. 3. (a) Photomicrograph showing oolites from the lower Macumber Formation, and compactional features (arrows). Plane polarized light, long axis of the picture is $9.5 \mathrm{~mm}$. Sampling site \#15, Whycocomagh. Sample skb93-56. (b) Photomicrograph showing stromatolitic laminites with grumeleuse texture (arrows). Laminite boundaries are accentuated by solution seams " $S$ ". The central layer is rich in coproliths " $C$ ". Plane polarized light, long axis of the picture is $7.2 \mathrm{~mm}$. Sampling site \#8, east Lake Ainslie. Sample skb93-60.

sedimentation or collapse breccia in the outcrops examined. Detailed petrography of thin sections does not reveal drastic dissolution or a cement fabric characteristic of meteoric diagenesis.

In summary, based on petrography, post-depositional processes that have affected the Macumber Formation include by nine distinct events which occurred in the following order: (1) precipitation of evaporites (nodules and isolated crystals); (2) mineralogical stabilization of metastable sedimented carbonates; (3) dissolution of evaporites; (4) mechanical compaction; (5) cementation by anhedral calcite; (6) chemical 

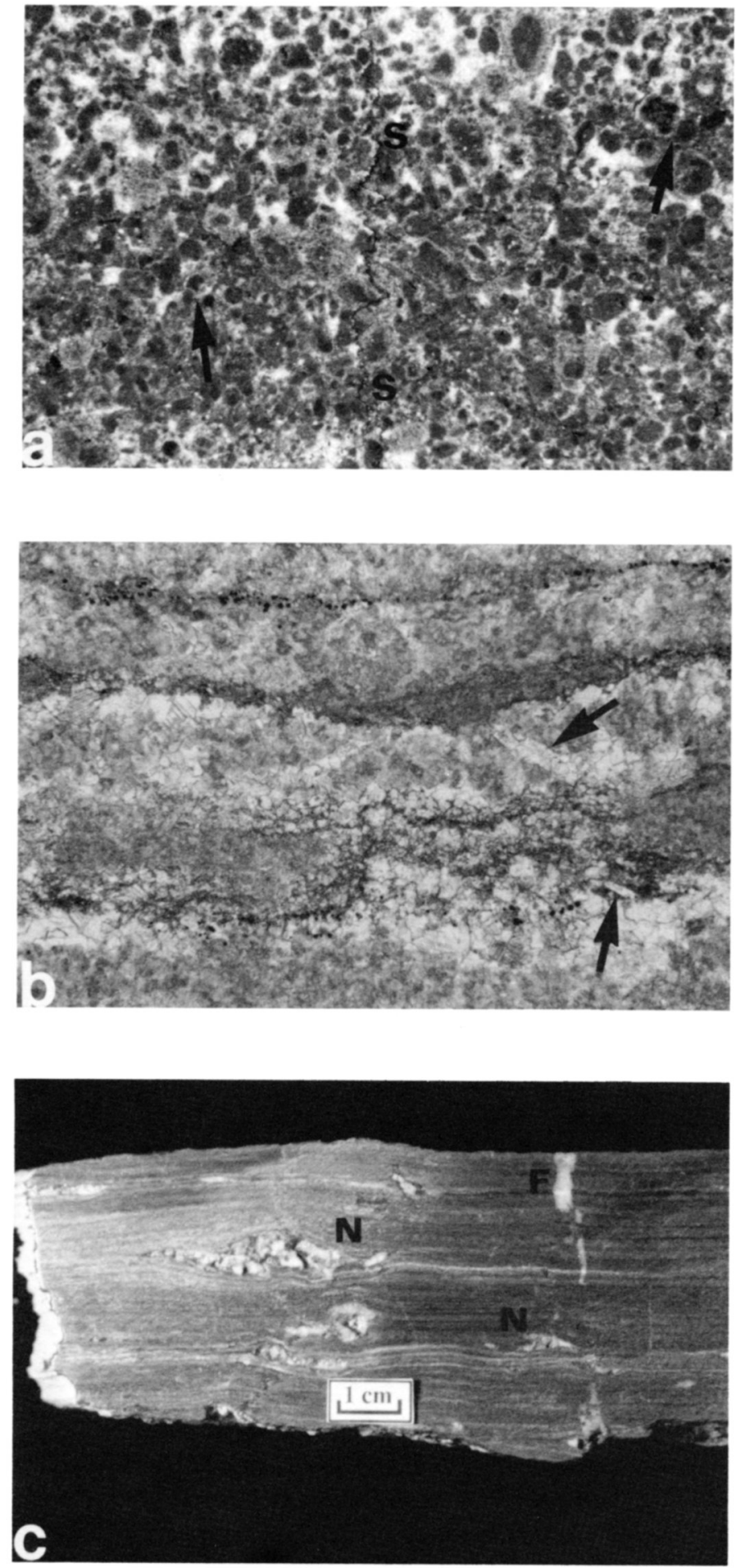

Fig. 4. (a) Photomicrograph of the peloidal and oolitic basal unit showing mechanical compaction features (arrows), cemented by late calcite (white) and later affected by vertical stylolites "S". Plane polarized light, long axis of the picture is $7.2 \mathrm{~mm}$. Sampling site \#8, east Lake Ainslie. Sample skb93-63. (b). Photomicrograph of stromatolitic layers from the upper unit, showing evaporite pseudomorphs (arrows) replaced by calcite. Plane polarized light, long axis of the picture is $7.2 \mathrm{~mm}$. Sampling site \#12, Meander River. Sample skb93-48. (c) Photograph of a slab showing compacted evaporite nodules "N", partly dissolved and filled with late calcite. A vertical fracture "F" filled with calcite, has been affected by horizontal displacement. Sampling site \#25, Upper Middle River. Sample 93FF-284.

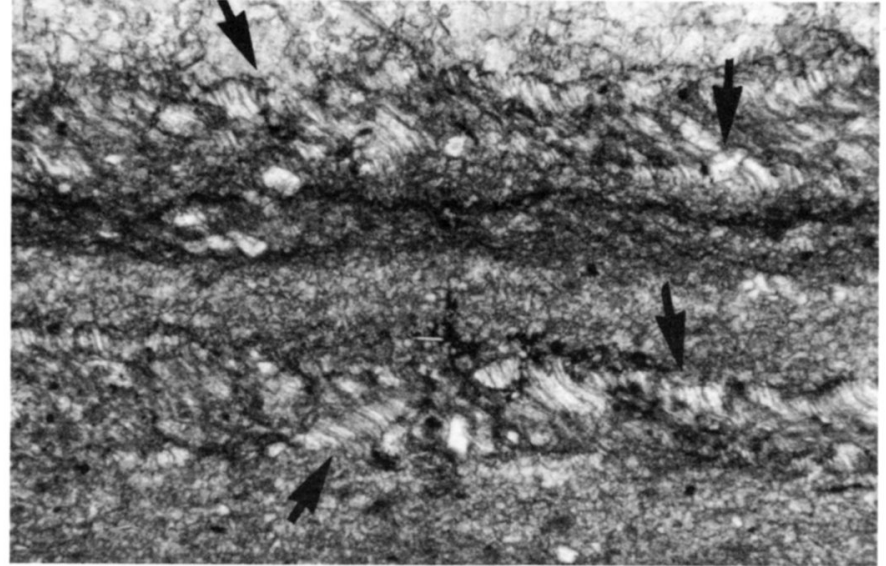

Fig. 5. Photomicrograph showing shear-related fibrous calcite (arrows). Displacement of solution seams by fibrous calcite (lower right arrow) suggest that shearing is post-chemical compaction. Plane polarized light, long axis of the picture is $1.8 \mathrm{~mm}$. Sampling site \#13, Port Hasting. Sample skb93-26.

compaction (solution seams and stylolites); (7) shearing; (8) vertical fracturing; and (9) final cementation by anhedral calcite.

\section{ISOTOPE GEOCHEMISTRY - RESULTS}

$\delta^{18} \mathrm{O}_{\mathrm{PDB}}$-values of whole rock samples from the stromatolitic (top) and oolitic (basal) units, and microsamples of the anhedral, inclusion-free calcite cement have been compared on histograms (Fig. 6). Whole rock samples show a broad range of values (Fig. 6a,b). Eighty-six percent of the values obtained for the top unit are above the minimum theoretical (Popp et al., 1986; Lohmann and Walker, 1989), marine Visean calcite signal $(-4.0 \%$ ) whereas $60 \%$ of the basal unit samples are above this value. The heaviest ratios are also found in samples from the top unit (Table 1, Fig. 6). The results obtained for the late cements fall in a range of values exclusively under the marine Visean signal ( -4.8 to $-13.0 \%$, Fig. 6c, Table 1), regardless of their stratigraphic position.

In $\delta^{18} \mathrm{O}-\delta^{13} \mathrm{C}$ space (Fig. 7a), the data set has been separated into two populations on the basis of distinctive $\delta^{13} \mathrm{C}$ results. Population 1 groups analyses from the lower oolitic unit, the upper stromatolitic unit and calcite cements, and is recorded from western to eastern outcrops indicating no regional systematic variations (Table 1, Fig. $7 \mathrm{a}$ ). The trend is characterized by a large variation of $\delta^{18} \mathrm{O}_{\mathrm{PDB}}$ values $(-12.8$ to $+1.2 \%)$ and typically heavy $\delta^{13} \mathrm{C}$ values $(+3$ to $+5.8 \%$ ). For the same $\delta^{18} \mathrm{O}_{\mathrm{PDB}}$ range, population 2 has a lower mean $\delta^{13} \mathrm{C}$ value $(0.5 \%)$; it is restricted to the western domain (see Figs. 2, 7a), suggesting the presence of a local source of isotopically light carbon. The most depleted ${ }^{13} \mathrm{C}$ samples do not carry the lighest oxygen or the highest ${ }^{87} \mathrm{Sr} / 86 \mathrm{Sr}$ ratios (Fig. 7, Table 1).

Many samples have $\delta^{18} \mathrm{O}_{\mathrm{PDB}}$ values within the expected range for calcite in equilibrium with Visean seawater but 23 samples are heavier $(-1.5$ to $+1.2 \%)$ than the marine 

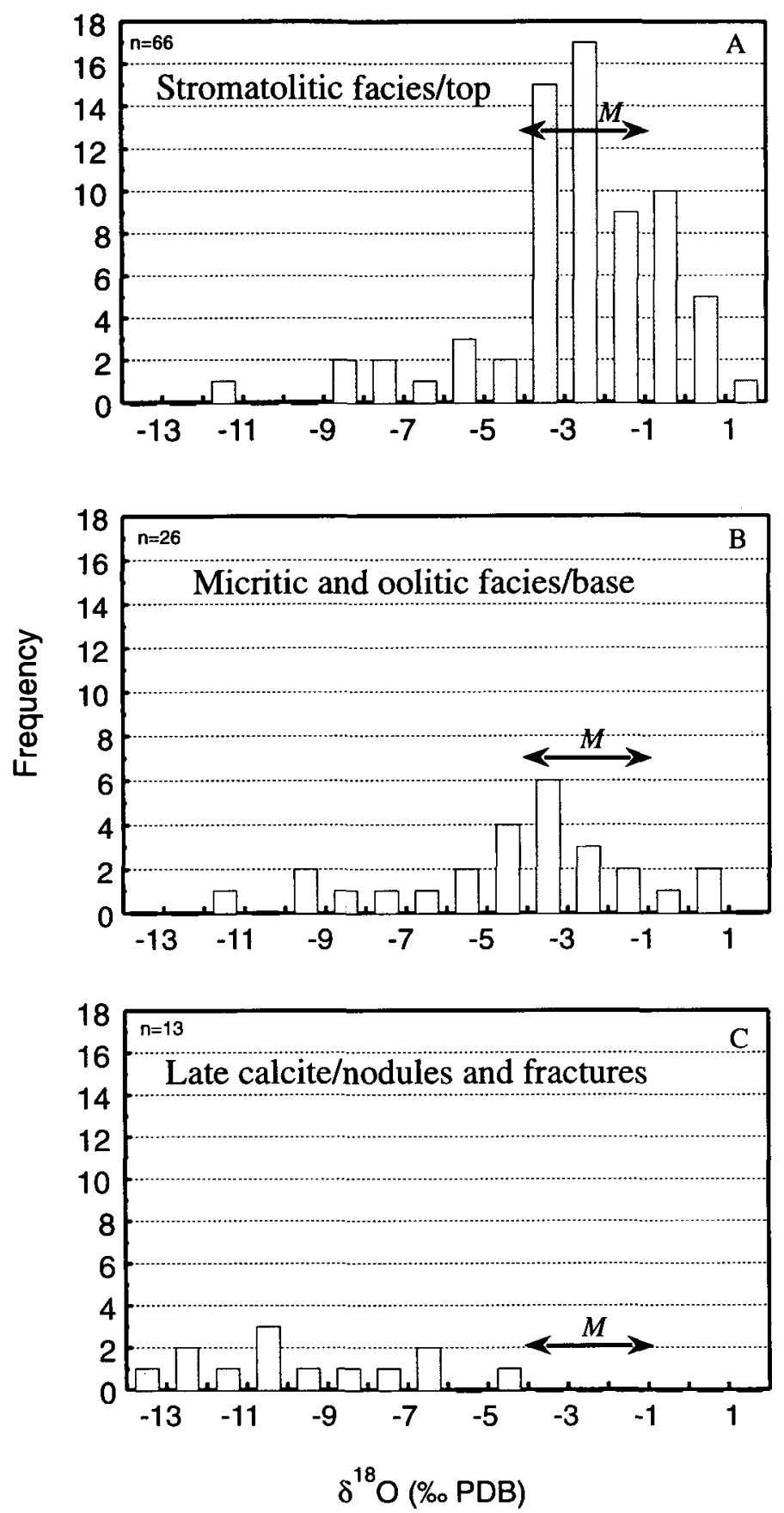

Fig. 6. Histograms showing $\delta^{18} \mathrm{O}$ values relative to $\mathrm{PDB}$ of the Macumber Formation for (A) stromatolitic facies (upper unit), (B) oolitic facies (basal unit) and (C) for separated late calcite cement from all units of the Macumber Formation. " $M$ " represents the isotopic field for calcite in equilibrium with Visean seawater (Popp et al., 1986; Lohmann and Walker, 1989).

signals, and 28 samples are lighter (-13.0 to $-5.4 \%$ ) than the hypothetical meteoric water signal (HMWL, Fig. 7a). Within individual samples, late calcite cements show $\delta^{18} \mathrm{O}_{\mathrm{PDB}}$ values lower than the whole rock values by 5 to $8 \%$, but similar $\delta^{13} \mathrm{C}$ values (Table 1, e.g., location 11, sample 213; location 13, samples 210, 211 and 212). This is also visible regionally in the overall trend of the late cements (Table 1). Two samples of late anhedral cement extracted from the same nodule show very distinct signals: -6.0 and $-10.6 \% \delta^{18} \mathrm{O}_{\mathrm{PDB}}$

Table 1. Geochemical results.

\begin{tabular}{|c|c|c|c|c|c|c|}
\hline Location & Sample & Phase & $\delta^{\prime 8} \boldsymbol{O}_{V P D B}$ & $8^{13} \mathrm{C}$ & ${ }^{87} \mathrm{Sr}{ }^{\beta 6} \mathrm{Sr}$ & $S r(p p m)$ \\
\hline & ts-620 & c-fract & -8.0 & 0.6 & & \\
\hline 2 & G1 & $\mathrm{m}$ & -2.6 & 4.6 & & \\
\hline 2 & $\mathrm{H}$ & $\mathrm{m}$ & -3.1 & 3.9 & 0.707701 & 3818 \\
\hline 2 & $\mathrm{Hl}$ & $\mathrm{m}$ & -1.3 & 4.2 & & \\
\hline 2 & $\mathbf{J}$ & $\mathrm{m}$ & -0.2 & 4.1 & & \\
\hline 2 & $\mathrm{~J} 1$ & $\mathrm{~m}$ & 0.2 & 4.2 & 0.707652 & 2997 \\
\hline 3 & ly- 658 & c-fract & -10.9 & 0.8 & & \\
\hline 3 & B & $\mathrm{m}$ & -3.4 & 3.1 & & \\
\hline 3 & BI & $\mathrm{m}$ & -3.3 & 3.5 & & \\
\hline 3 & E & $\mathrm{m}$ & -2.3 & 5.5 & & \\
\hline 3 & E1 & $\mathrm{m}$ & -3.6 & 4.5 & & \\
\hline 3 & G & $\mathrm{m}$ & -3.0 & 4.4 & & \\
\hline 3 & I & $\mathrm{m}$ & -2.2 & 3.5 & & \\
\hline 3 & II & $\mathrm{m}$ & -2.3 & 3.5 & & \\
\hline 3 & $93-402 \mathrm{~A}$ & o & -0.7 & 3.6 & 0.707759 & 308 \\
\hline 3 & $93-402 B$ & 0 & -1.7 & 3.3 & & \\
\hline 3 & A & 0 & -5.7 & 2.4 & 0.708577 & 247 \\
\hline 3 & Al & 0 & -5.9 & 2.4 & & \\
\hline 3 & $93-402 \mathrm{C}$ & $\mathbf{m}$ & -2.5 & 2.5 & & \\
\hline 3 & $93-402 \mathrm{D}$ & $\mathrm{m}$ & -2.1 & 3.4 & & \\
\hline 5 & tr-665a & $\mathrm{m}$ & -4.4 & 3.5 & & \\
\hline 5 & tr $-666 a$ & c-nod & -9.1 & 3.4 & & \\
\hline 5 & tr $-666 c$ & c-fract & -7.2 & 2.8 & & \\
\hline 5 & $\mathrm{~K}$ & $\mathbf{m}$ & -2.0 & 4.3 & & \\
\hline 5 & $\mathrm{~K} 1$ & $\mathrm{~m}$ & -1.7 & 4.4 & & \\
\hline 5 & $\mathrm{~L}$ & $\mathrm{~m}$ & -2.4 & 4.2 & & \\
\hline 5 & $\mathrm{Ll}$ & $\mathrm{m}$ & -2.5 & 4.3 & & \\
\hline 5 & M & $\mathrm{m}$ & -3.3 & 4.1 & & \\
\hline 5 & M1 & $\mathrm{m}$ & -3.4 & 4.1 & & \\
\hline 5 & $\mathrm{~N}$ & $\mathrm{~m}$ & -3.2 & 4.4 & & \\
\hline 5 & N1 & $\mathrm{m}$ & -2.7 & 4.2 & & \\
\hline 5 & $\mathrm{O}$ & $\mathrm{m}$ & -3.1 & 4.2 & & \\
\hline 5 & $\mathrm{O} 1$ & $\mathrm{~m}$ & -3.1 & 4.1 & & \\
\hline 9 & 63 & o & -2.9 & 2.2 & & \\
\hline 9 & $93-73$ & c-nod & -4.8 & 0.5 & & \\
\hline 9 & $\mathrm{~T}$ & $\mathrm{~m}$ & 0.3 & 2.7 & & \\
\hline 9 & $\mathrm{U}$ & $\mathrm{m}$ & -0.7 & -1.7 & 0.707741 & 395 \\
\hline 9 & 60 & $\mathrm{~m}$ & -1.8 & 3.6 & & \\
\hline 9 & 65 & o & -4.9 & 3.2 & 0.708200 & 285 \\
\hline 9 & 68 & $\mathrm{~m}$ & -2.7 & 4.1 & 0.707764 & 515 \\
\hline 9 & $93-72$ & 0 & -2.6 & 2.1 & & \\
\hline 9 & $93-68$ & $\mathrm{~m}$ & -3.9 & 0.7 & & \\
\hline 9 & $93-71$ & o & -3.7 & 3.9 & & \\
\hline 9 & $93-73$ & $\mathrm{~m}$ & -1.6 & 3.9 & & \\
\hline 10 & $33 \mathrm{~b}$ & $\mathrm{~m}$ & -2.1 & 4.2 & & \\
\hline 10 & mull & c & -6.4 & 3.2 & & \\
\hline 10 & $\mathrm{~V}$ & $\mathrm{~m}$ & -0.4 & 4.0 & & \\
\hline 10 & W & $\mathrm{m}$ & -1.1 & 4.3 & & \\
\hline 10 & 28 & o & -6.3 & 0.3 & 0.708033 & 404 \\
\hline 10 & 32 & 0 & 0.2 & 4.6 & & \\
\hline 10 & 34 & 0 & -4.1 & 3.6 & 0.707771 & 497 \\
\hline
\end{tabular}

0.707771497

0.708017322

0.70766150

$0.707899 \quad 498$

$\begin{array}{lllll}13 & 26 & \mathrm{~m} & -7.4 & 4.4 \\ 13 & 23 \mathrm{~b} & \mathrm{c}-\text { fract } & -10.1 & 3.3\end{array}$

$13 \quad 211 \quad$ c-nod $\quad-10.6 \quad 3.2$

$211 \quad$ c-nod $\quad-6.0 \quad 3.2$

at $3.2 \% \delta^{13} \mathrm{C}$ (Table 1 , sample 211 ), suggesting a progressive depletion in 180 during calcite cementation.

Most ${ }^{87} \mathrm{Sr} / 86 \mathrm{Sr}$ ratios obtained (Fig. $7 \mathrm{~b}, \mathrm{c}$ ) are lower than the global Visean seawater ratios (Smalley et al., 1994), suggesting that the Sr pool was locally influenced by a non- 
Table $1 .$.

\begin{tabular}{|c|c|c|c|c|c|c|}
\hline Location & Sample & Phase & $\delta^{18} \boldsymbol{O}_{V P D B}$ & $\delta^{13} \mathrm{C}$ & ${ }^{87} \mathrm{Sr} r^{\beta 6} \mathrm{Sr}$ & $S \boldsymbol{r}(p p m)$ \\
\hline 13 & 210 & c-fract & -12.4 & 3.3 & & \\
\hline 13 & $23 a$ & 0 & -11.7 & 3.6 & 0.707739 & 423 \\
\hline 13 & 25 & 0 & -8.2 & 3.7 & 0.707847 & 373 \\
\hline 13 & $26-1$ & 0 & -7.6 & 5.8 & 0.708171 & 893 \\
\hline 13 & 23 & m & -11.4 & 3.1 & & \\
\hline 13 & 210 & $\mathrm{~m}$ & -6.3 & 3.1 & & \\
\hline 13 & 211 & $\mathrm{~m}$ & -2.7 & 4.2 & & \\
\hline 15 & 57 & $\mathrm{~m}$ & -8.3 & 4.1 & 0.707966 & 466 \\
\hline 15 & $56 a$ & 0 & -9.4 & 4.2 & & \\
\hline 15 & $56 \mathrm{~b}$ & o & -9.7 & 4.3 & 0.707749 & 301 \\
\hline 19 & $93 \mathrm{FF}-217 \mathrm{~B} 2$ & $\mathrm{~m}$ & -1.5 & 3.9 & & \\
\hline 19 & $93 F F-221 A$ & 0 & -3.0 & 4.2 & & \\
\hline 19 & $93 \mathrm{FF}-222 \mathrm{~A}$ & 0 & -3.7 & 4.3 & & \\
\hline 19 & 93FF-223B & $\mathrm{m}$ & -3.0 & 4.3 & & \\
\hline 19 & $93 \mathrm{FF}-223 \mathrm{~B}$ & $\mathrm{~m}$ & -0.9 & 4.7 & & \\
\hline 19 & 93FF-224 & $\mathrm{m}$ & -3.1 & 4.5 & & \\
\hline 20 & 93FF-019A & o & -1.9 & 4.6 & & \\
\hline 20 & $93 \mathrm{FF}-019 \mathrm{~b}$ & $\mathrm{~m}$ & -2.2 & 4.7 & & \\
\hline 20 & 93FF-039D & o & -3.5 & 4.4 & & \\
\hline 20 & 93FF-039e & $\mathrm{m}$ & -2.5 & 4.3 & & \\
\hline 20 & $93 \mathrm{FF}-060 \mathrm{~B}$ & $\mathbf{m}$ & -1.2 & 4.5 & & \\
\hline 20 & $93 \mathrm{FF}-2$ & 0 & -3.2 & 3.0 & & \\
\hline 22 & $93 \mathrm{FF}-120 \mathrm{C}$ & $\mathrm{m}$ & -5.8 & 4.7 & & \\
\hline 22 & 93FF-120b & $\mathrm{m}$ & -7.9 & 4.4 & & \\
\hline 23 & 93FF-084B & 0 & -4.5 & 4.2 & & \\
\hline 24 & $93 \mathrm{FF}-122$ & $\mathrm{~m}$ & -4.3 & 4.3 & & \\
\hline 24 & 93FF-137B1 & $\mathrm{m}$ & -0.4 & 4.5 & & \\
\hline 24 & $93 \mathrm{FF}-159 \mathrm{~B}$ & $m$ & -2.9 & 4.3 & & \\
\hline 24 & $93 \mathrm{FF}-161 \mathrm{~b}$ & $\mathrm{~m}$ & -3.9 & 4.2 & & \\
\hline 24 & $93 \mathrm{FF}-165 \mathrm{~B}$ & $\mathrm{~m}$ & -3.3 & 4.1 & & \\
\hline 24 & $93 \mathrm{FF}-216$ & 0 & -4.2 & 4.5 & & \\
\hline 24 & 52 & 0 & & & 0.707823 & 531 \\
\hline 24 & 51 & $\mathrm{~m}$ & -0.6 & 4.4 & & \\
\hline 24 & 54 & o & 0.1 & 4.9 & 0.707747 & 10175 \\
\hline 24 & 207 & $\mathbf{m}$ & 0.4 & 3.8 & & \\
\hline 24 & 208 & $\mathrm{~m}$ & -0.2 & 4.2 & & \\
\hline 25 & 93FF-255B & 0 & -1.8 & 4.7 & & \\
\hline 25 & $93 \mathrm{FF}-256 \mathrm{~B}$ & $\mathrm{~m}$ & -0.5 & 4.5 & & \\
\hline 25 & $93 F F-258 \mathrm{~A}$ & $m$ & -0.4 & 4.5 & & \\
\hline
\end{tabular}

radiogenic source and was isolated from the global oceanic reservoir. This suggestion implies that the sedimentary environment was not an open sea but a restricted body of marine water and is supported by the faunal assemblage of subzone A (Mamet, 1970; Geldsetzer, 1977), and by the importance of the overlying evaporite succession in the Windsor Group.

The isotopic ratios represented in the $\delta^{180} \mathrm{O}-{ }^{87} \mathrm{Sr} / 86 \mathrm{Sr}$ plot show two end-member trends envelopping the entire spread of data (Fig. 7b). Trend 1 has uniform ${ }^{87} \mathrm{Sr} / 86 \mathrm{Sr}$ and highly variable $\delta^{18} \mathrm{O}_{\mathrm{PDB}}$ values, and trend 2 shows highly variable ratios for both tracers. Samples most depleted in $18 \mathrm{O}$, possibly representing a high water/rock ratio (W/R), show non-radiogenic ${ }^{87} \mathrm{Sr} / 86 \mathrm{Sr}$ in trend 1 , but radiogenic ratios in trend 2 . The most radiogenic ${ }^{87} \mathrm{Sr} / 86 \mathrm{Sr}$ ratios belong to the basal unit (Fig. 7b,c). Two sources of Sr clearly

Fig. 7. (A) Scatterplot of $\delta^{13} \mathrm{C}$ vs $\delta^{18} \mathrm{O}$. Sampling locations are indicated as data labels. A cluster of 66 points for samples from all sites is represented by the " $C$ " field. A broad range of $\delta^{18} \mathrm{O}$ values is recorded, with a relatively narrower variation of $\delta^{13} \mathrm{C}$ values. For population 1 the $\delta^{13} \mathrm{C}$ values cluster around the marine carbon signal of +3 to $+4 \%$, whereas for population 2 , the value is lower, at around $0.5 \%$. Grey box " $\mathrm{M}$ " indicates isotopic composition of calcites in equilibrium with Visean seawater (Lohmann and Walker, 1989; Popp et al., 1986). The hypothetical meteoric water line (HMWL) is calculated for a paleolatitude of 10 to $15^{\circ} \mathrm{S}$ (Hamblin and Rust, 1989), and for a surficial temperature
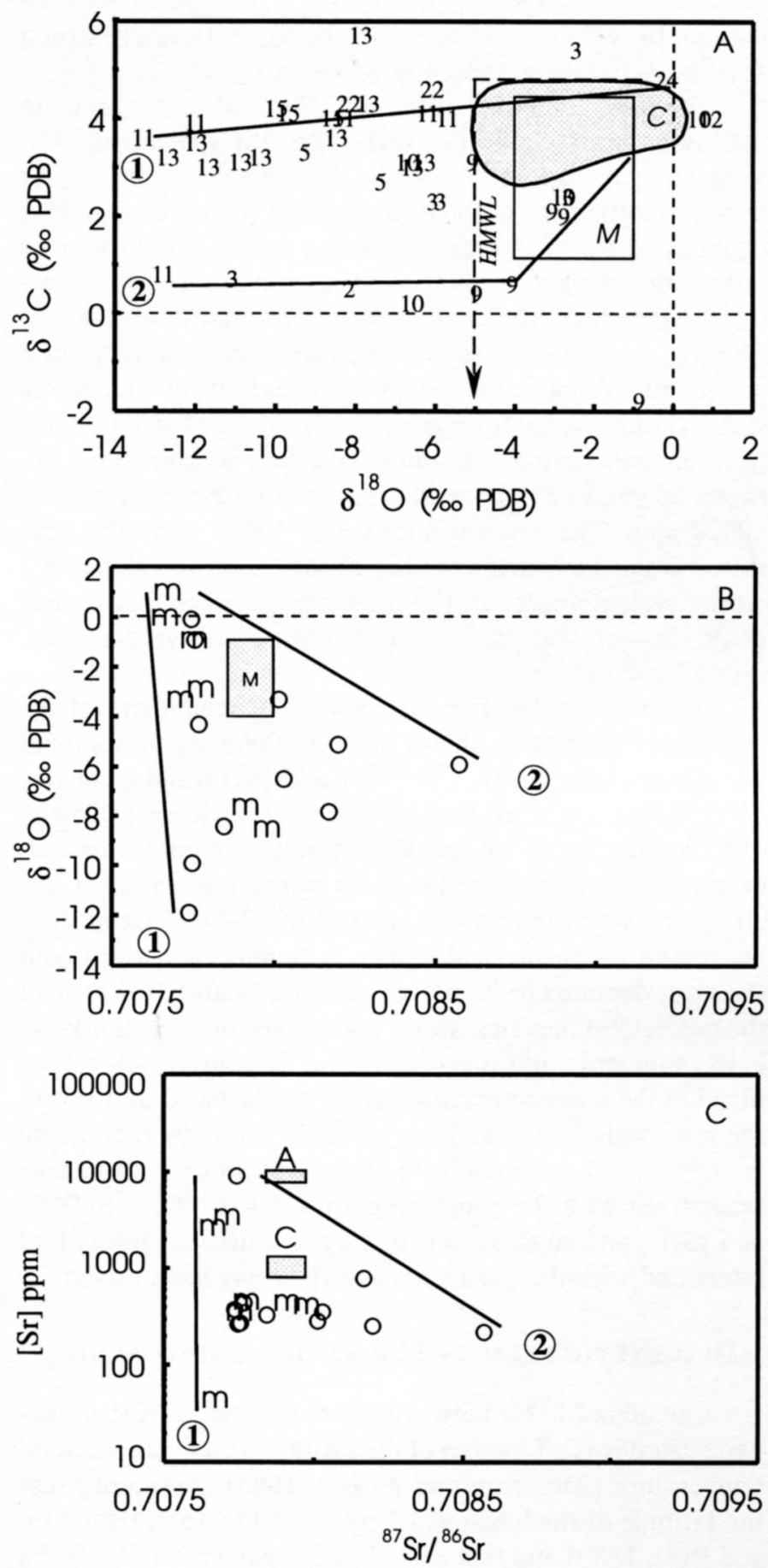

of $20^{\circ} \mathrm{C}$ (Anderson and Arthur, 1983). (B) Scatterplot of $\delta^{18} \mathrm{O}$ vs ${ }^{87} \mathrm{Sr} /{ }^{86} \mathrm{Sr}$ for micritic " $m$ " and colitic " 0 " samples of the Macumber units. Trend 1 shows significant variations of $\delta^{18} \mathrm{O}$ values with practically no changes in ${ }^{87} \mathrm{Sr} /{ }^{86} \mathrm{Sr}$, whereas trend 2 represents an end-member where both tracers vary significantly. Grey box indicates isotopic composition of calcites in equilibrium with Visean seawater (Lohmann and Walker, 1989; Smalley et al., 1994). (C) Scatterplot of [Sr] vs ${ }^{87} \mathrm{Sr} /{ }^{86} \mathrm{Sr}$ for samples of the micritic " $\mathrm{m}$ " and oolitic "o" units. End-member trends 1 and 2 enclose the entire field of data. Trend 1 shows no variation of ${ }^{87} \mathrm{Sr} /{ }^{86} \mathrm{Sr}$ for drastic changes in $[\mathrm{Sr}$ ], whereas trend 2 shows significant variations for both tracers. Grey boxes indicate $\mathrm{Sr}$ concentrations and isotopic ratios for aragonite " $A$ " and calcite " $C$ " in equilibrium with Visean seawater (Veizer, 1983; Smalley et al., 1994). 
influenced the diagenetic evolution of the Macumber Formation, the effect of radiogenic Sr being particularly strong at its base and geographically widespread.

The radiogenic tail of trend 2 (Fig. $7 \mathrm{~b}$ ) corresponds to the lowest bulk [Sr] in the $[\mathrm{Sr}]-87 \mathrm{Sr} /{ }^{86} \mathrm{Sr}$ space (Fig. $7 \mathrm{c}$ ), suggesting incorporation of allochtonous (non-marine) $\mathrm{Sr}$ during stabilization of the limestones. A broad range of [Sr] is obtained for ${ }^{87} \mathrm{Sr} / 86 \mathrm{Sr}$ below and at the Visean marine ratio, suggesting that many samples contain marine $\mathrm{Sr}$ derived either from the sediments or from interstitial water. The [Sr] range ( $<100$ to $10000 \mathrm{ppm})$ is characteristic of a mixed mineralogy assemblage that underwent diagenetic stabilization. According to Veizer (1983), calcites in equilibrium with normal seawater have $\mathrm{Sr}$ concentrations between 800 and $1200 \mathrm{ppm}$ whereas aragonite can have up to $10000 \mathrm{ppm}$. The concentrations near $10000 \mathrm{ppm}$ likely resulted from the transformation of aragonite to calcite in a closed system and/or in the presence of saline, non-radiogenic, Sr-rich waters. The lower values are typical of recrystallized calcite.

In summary, the regional isotope geochemistry of the Macumber Formation shows that: (1) there are no regional variations in the $\delta^{18} \mathrm{O},{ }^{87} \mathrm{Sr} / 86 \mathrm{Sr}$ and [Sr] trends, but low $\delta^{13} \mathrm{C}$ values are restricted to western locations; (2) many $\delta^{18} \mathrm{O}$ values are above the Visean marine signal, this tendency being more pronounced for upper unit samples; (3) all samples considered, the overall $\delta^{13} \mathrm{C}-\delta^{18} \mathrm{O}$ trend does not match the theoretical meteoric diagenesis pattern, and the most depleted $\delta^{18} \mathrm{O}$ values are significantly lower than the theoretical meteoric water signal (see next section); (4) both radiogenic and non-radiogenic Sr sources are recognized in the diagenetic carbonates; (5) the basal unit shows the most radiogenic, and the top unit, the least radiogenic ${ }^{87} \mathrm{Sr} /{ }^{86} \mathrm{Sr}$; (6) end-member populations and trends can be recognized with the geochemical tracers $\left(\delta^{18} \mathrm{O},{ }^{87} \mathrm{Sr} /{ }^{86} \mathrm{Sr}\right.$ and [Sr]), and suggest imprints by two distinct fluids that interacted with the sediments and that may have mixed.

\section{Diagenetic fluids - BuRIAL diagenesis MODEL}

Calculated $\delta^{18} \mathrm{O}$ between meteoric and marine diagenetic calcites is a function of the latitude and mean surficial temperature (Anderson and Arthur, 1983). Assuming that the latitude of the basin was between 10 to $15^{\circ} \mathrm{S}$ (Hamblin and Rust, 1989) and that early Visean marine calcites had a $\delta^{18} \mathrm{O}_{\mathrm{PDB}}$ value of $-2 \%$ (Lohmann and Walker, 1989), their coeval meteoric counterparts should not be depleted by more than 3\%o (Anderson and Arthur, 1983), i.e., they should not have $\delta^{18} \mathrm{O}_{\mathrm{PDB}}$ values lower than $-5 \%$ (HMWL, Fig. 7a). This constitutes a conservative estimate because the Visean marine signal in the study area could have been even heavier than $-2 \%$ due to evaporative effects. An accurate estimate of the exact composition of ancient meteoric waters depends on knowledge of nearby relief. However, because a large part of our trend falls considerably below $-5 \%$, and does not show affinities with meteoric systems such as the well known " $J$ " curve of Lohmann (1988) or the "L" curve of AlAasm and Veizer (1986), a meteoric influence in the diagenesis of the Macumber Formation is not indicated. The trends instead show the typical profile of burial diagenetic systems, evolving from surficial marine signals, to progressively lighter $\delta^{18} \mathrm{O}$ values, without marked depletion of $\delta^{13} \mathrm{C}$ values at high $W / R$ (low $\delta^{18} O$ values) (i.e., Choquette and James, 1990).

With $\delta^{18} \mathrm{O}$ being a good indicator of parent fluid salinity and temperature of precipitation, the clear tendency towards heavier values for the top unit likely reflects conditions of precipitation and/or recrystallization distinct from its basal counterpart. These conditions could have been governed by circulation of hypersaline waters from the evaporites to the top unit, and of fluids mainly derived from the permeable clastic rocks of the Horton Group to the basal unit.

Samples with low $\delta^{13} \mathrm{C}$ values suggest incorporation of light carbon bicarbonates through shallow-burial decarboxylation of organic components (Tissot and Welte, 1984). These samples are restricted to the western domain (Fig. 7a, population 2). This, together with traces of hydrocarbons and bitumen common on thin sections, indicates that the Macumber Formation was locally rich in organic components. Numerous hydrocarbon seeps sourced to the Horton Group exist near Lake Ainslie and constitute a likely source of light carbon (Utting and Hamblin, 1991; Fowler et al., 1993).

The covariations of $\delta^{18} \mathrm{O}$ with ${ }^{87} \mathrm{Sr} /{ }^{86} \mathrm{Sr}$ and [Sr] suggest two sources for Sr: seawater and the interstitial waters of evaporites represent a non-radiogenic source, and the clastic rocks of the Horton Group, mainly derived from plutonic rocks, represent a radiogenic source (e.g., White et al., 1990).

Incorporation of heavy $\delta^{18} \mathrm{O}_{\mathrm{PDB}}$ and non-radiogenic ${ }^{87} \mathrm{Sr} / 86 \mathrm{Sr}$ during growth of biogenic components in a restricted and saline environment, coupled with early diagenetic processes such as evaporite precipitation and possibly early cementation, have produced the heavy $\delta^{18} \mathrm{O}_{\mathrm{PDB}}$ and non-radiogenic character of the Macumber Formation. Burial has produced limestones with lighter $\delta^{18} \mathrm{O}_{\mathrm{PDB}}$ due to the decrease of fractionation at higher temperatures, and with higher ${ }^{87} \mathrm{Sr} /{ }^{86} \mathrm{Sr}$ in the basal unit due to its exposure to hot fluids expelled from the underlying radiogenic clastic sediments. Hot fluids can leach $\mathrm{Sr}$ from clastic components and inherit a radiogenic signal.

Mixing of non-radiogenic, evaporitic fluids with radiogenic basinal waters and water/rock interaction during burial possibly produced intermediate isotopic values (Fig. 7). The uniformity of the $\mathrm{O}$ and $\mathrm{Sr}$ isotope trends throughout the study area suggests that the burial diagenetic system was relatively homogeneous on a regional scale (Table 1, Fig. 7a,b).

In summary, the petrographic and isotopic diagenetic features described above can all be explained by a simple burial model (Fig. 8). After sedimentation, seawater produced early precipitation of calcite cement and evaporites (Fig. 8a). As thicker evaporites were being deposited, formation water expelled from the Horton Group started to stabilize limestones, dissolve evaporites, precipitate calcite cement, and mix slowly with evaporite-related brines (Fig. 8b). At deeper burial depths (and higher temperatures), stabilization and cementation continued, producing carbonates with lower $\delta^{18} \mathrm{O}$ and higher ${ }^{87} \mathrm{Sr} /{ }^{86} \mathrm{Sr}$ (Fig. $8 \mathrm{C}$ ). 

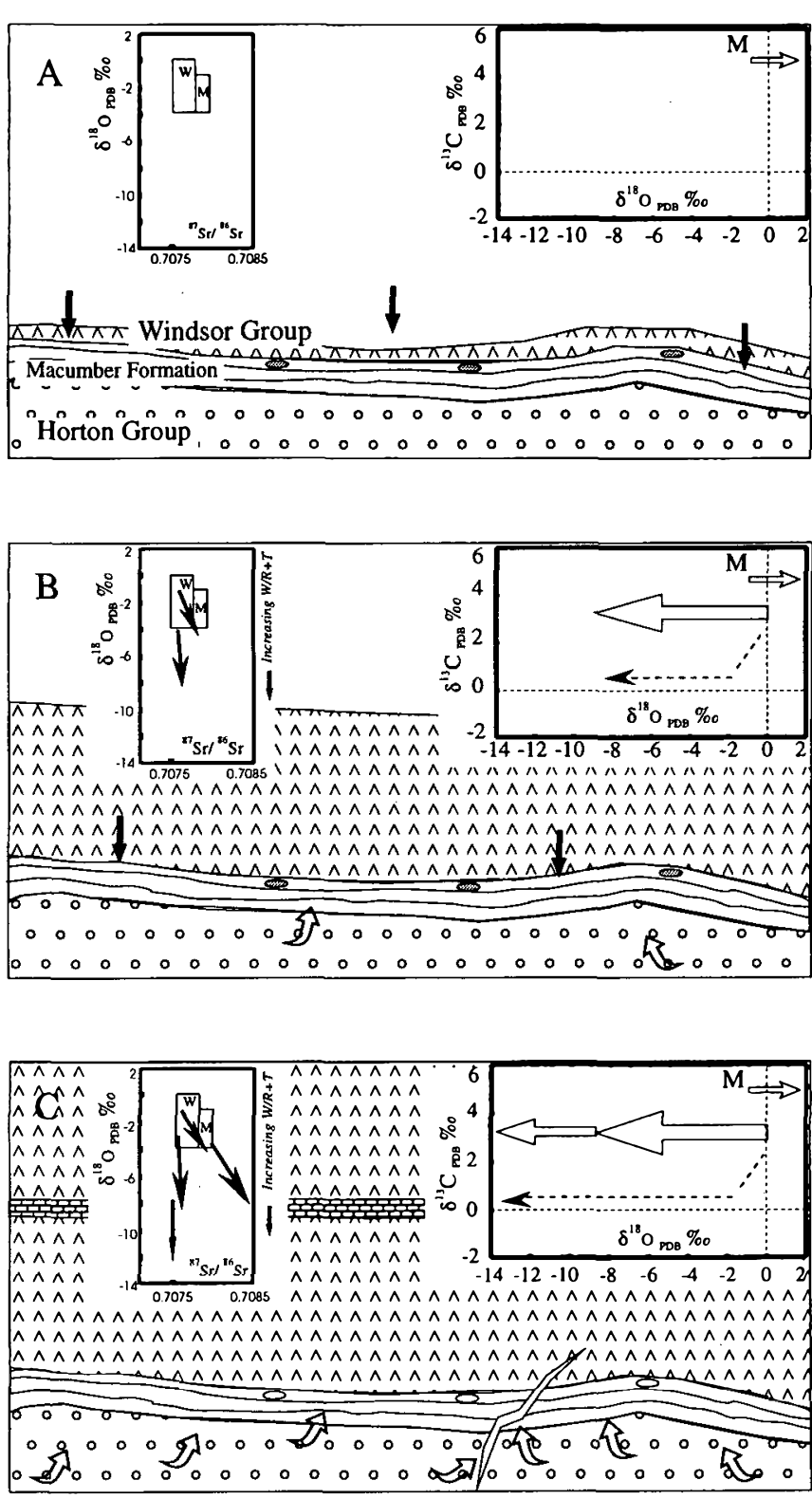

Fig. 8. Diagenetic model for the Macumber Formation (not to scale). Departures from Visean marine $\delta^{18} \mathrm{O}$ signals by Macumber carbonates were caused both by evaporitic enrichment in ${ }^{18} \mathrm{O}$ and lowering of oxygen fractionation factor at high temperature. The produced trends are illustrated by arrows on $\delta^{18} \mathrm{O}_{\mathrm{PDB}}{ }^{-87} \mathrm{Sr} /$ ${ }^{86} \mathrm{Sr}$ and $\delta^{13} \mathrm{C}-\delta^{18} \mathrm{O}_{\mathrm{PDB}}$ plots. (A) Evaporite-derived brines directly precipitated calcite and evaporite nodules in the top unit, and/or shifted the signals of metastable marine carbonates to the "W" box, to the left of the expected Visean marine values "M". (B) Recrystallization and precipitation of carbonates in the top and basal units during progressively increasing temperature and burial caused a lowering of $\delta^{18} \mathrm{O}$ values. Samples depleted in $13 \mathrm{C}$ probably derived some light carbon from oxidation of organic matter, the Macumber Formation being locally rich in petroleum (see text). (C) At high temperature, radiogenic water was expulsed from the Horton Group producing the end-member isotope ratios of the carbonates, and low $\delta^{18} \mathrm{O}$ values resulted from lower oxygen fractionation at higher temperatures.

\section{TECTONO-STRATIGRAPHIC EVOLUTION - DISCUSSION}

The stratigraphic succession of the Maritimes Basin in western Cape Breton Island is marked by important and conspicuous gaps in the stratigraphy which occur systematically above the Macumber Formation. The missing stratigraphy may be accounted for by either: (1) an extensional detachment fault running along the contact between the limestones of the Macumber Formation and overlying evaporites, which have highly contrasting rheologic properties (Lynch and Giles, in press); or (2) a local unconformity. The diagenetic history of the Macumber Formation as documented here provides important new data which can distinguish between the presence of a detachment fault or unconformity along the top of the Macumber Formation.

The unconformity processes should produce collapse breccias and weathering (e.g., Kelley, 1967; Gibling et al., 1987). Field evidence such as soil formation, calcrete, karsts and surface breccia could also indicate erosion. The Macumber Formation underlying unconformities, especially where covered with continental rocks of the Mabou Group, should show karsting and petrographic features such as solution pipes, pendant and meniscus cements, and a geochemical profile typical of marine and burial diagenesis with a meteoric diagenesis overprint.

During the present study, field and petrographic features characteristic of sub-aerial erosion were not found (see also Lynch and Giles, in press; Lynch and Tremblay, 1994), and the diagenetic succession recognized by petrography and geochemistry does not include a meteoric component. Hence, the absence of features diagnostic of meteoric diagenesis is inconsistent with the presence of an important unconformity at the top of the Macumber Formation.

The detachment model proposes that the detachment plane occurs along the top of the Macumber Formation on Cape Breton Island, where it is in contact with a thick evaporite succession, and is referred to as the Ainslie detachment (Lynch and Giles, in press). The carbonates of the Macumber Formation would have acted as an upper crustal stress guide, controlling the propagation of the detachment which was active in Westphalian times (Lynch and Giles, in press). This mechanism should produce typical burial diagenetic features, followed by shearing in the Macumber Formation. The overall geochemical trends, from stabilization of fine grained sediments to late cementation, should indicate initial marine and progressive burial diagenesis. This model is fully supported by field and petrographic observations, and the geochemical characterization of the Macumber units is consistent with a burial diagenetic succession. Moreover, the observation of cleavage, shear-related, fibrous calcite along horizontal planes, recumbent folds and rotated nodules can all be interpreted as effects of bedding-parallel shear. These features post-date numerous burial processes as suggested by their cross-cutting solution seams (Fig. 5). Relative chronology (based on petrography) of shear-related fibrous calcite and 
fracture-filling late calcites ( ${ }^{18} \mathrm{OPDB}$ down to $-12.4 \%$, Table 1 , location 13) indicate that extension took place prior to thermal peaks of 75 to $95^{\circ} \mathrm{C}$ (i.e., at an estimated maximum burial depth of $2.0 \mathrm{~km}$ (Fig. 9)).

\section{Conclusion}

The Macumber Formation consists of fine grained carbonate sediments that were mostly impermeable throughout its diagenetic history. However, during and after lithification, evaporite dissolution, shearing and fracturing produced a heterogeneous secondary porosity in the formation. The succession of diagenetic events consists in precipitation of evaporites (nodules and isolated crystals), recrystallization (stabilization) of metastable marine carbonates, dissolution of evaporites, mechanical and chemical compaction (stylolitization) and late cementation. Petrography and isotope geochemistry indicate that all the processes have taken place in the marine and burial environments. Whole-rock samples from a few western locations have yielded $\delta^{13} \mathrm{C}$ values around $-0.5 \%$ interpreted as resulting from incorporation of light carbon through shallow-burial decarboxylation of hydrocarbons, concentrated in the western Macumber Formation.

The formation can be divided into two units, a top unit dominated by stromatolitic laminites and a basal unit dominated by ooid limestones. Non-radiogenic $\left(\delta^{18} \mathrm{O}_{\mathrm{PDB}}\right.$ between 1.5 and $-13 \%,{ }^{87} \mathrm{Sr} / 86 \mathrm{Sr}$ around 0.7075 ) and radiogenic $\left(\delta^{18} \mathrm{O}_{\mathrm{PDB}}\right.$ between 1.0 and $-8 \%$, ${ }^{87} \mathrm{Sr} / 86 \mathrm{Sr}$ between 0.7076 and 0.7085 ) diagenetic systems ( 1 and 2 in order), have largely affected the top and basal units, respectively. The recognized diagenetic fluids are marine brines (system 1) from the overlying evaporites, and formation waters (system 2) from the underlying Horton Group. These two fluids have mixed and dominated during the diagenetic evolution of the Macumber Formation, from near surface to maximum burial. This, in addition to the lack of erosional and meteoric diagenetic features, gives indirect support for the occurrence of a detachment fault along the upper contact of the Macumber Formation.

\section{ACKnowledgements}

This study is part of a multi-institutional research project supported by the Canada-Nova Scotia Mineral Development Agreement and by the Magdalen Basin NATMAP program. The first author is grateful to Dr. D.F. Sangster, co-proposer on the MDA project, for his help and advice. The authors are grateful to Drs. J. Paquette and $\mathrm{C}$. Viau for constructive reviews; to M.R. Luzincourt from the $\delta-L A B$ of the Geological Survey of Canada for all the stable isotope analyses; and to Drs. P. Giles, D. Kirkwood and B. Mamet for helpful discussions. Many thanks to Dr. Denis Lavoie from QGC for his constructive review of the first draft of the manuscript.

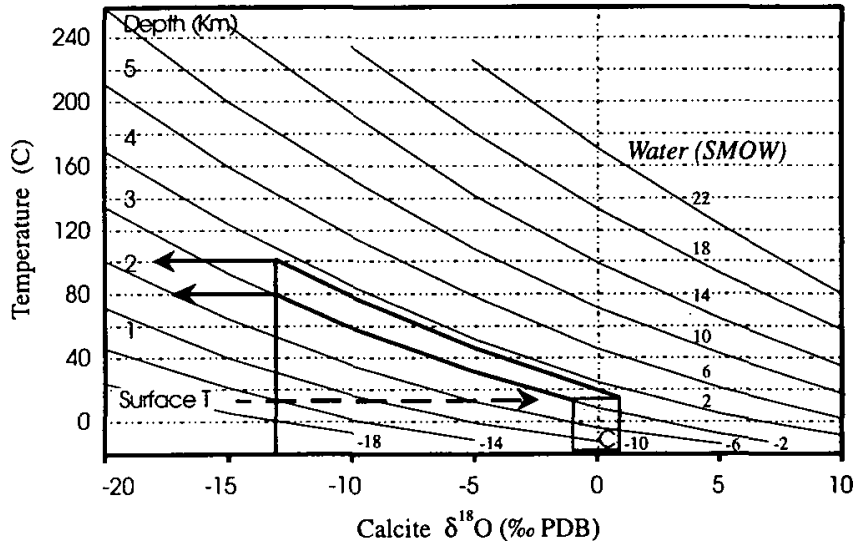

Fig. 9. Temperature of precipitation vs $\delta^{18} \mathrm{O}_{\mathrm{PDB}}$ of diagenetic calcites. Curves are constructed with the equation of Craig (1965):

$$
\begin{aligned}
\mathrm{T}^{\circ}(\mathrm{C})=16.9-4.2 & \left(\delta^{18} \mathrm{O}_{\text {cal }}(\mathrm{PDB})-\delta^{18} \mathrm{O}_{\text {wat }}(\mathrm{SMOW})\right. \\
& +0.13\left(\delta^{18} \mathrm{O}_{\text {cal }}(\mathrm{PDB})-\delta^{18} \mathrm{O}_{\text {wat }}(\mathrm{SMOW})\right)^{2} .
\end{aligned}
$$

The translation to burial depths $(\mathrm{km})$ is based on a geothermal gradient of $40^{\circ} \mathrm{C} / \mathrm{km}$ as suggested by the curve of Lister et al. (1991) for uniform stretching of the lithosphere in an extensional tectonic regime.

Assuming that the heavy marine $\delta^{18} \mathrm{O}_{\mathrm{PDB}}$ values $(-1.5$ to $1.5 \%$ ) of Macumber carbonates precipitated at $15^{\circ} \mathrm{C}$, a likely temperature for the advocated sedimentary environment, parent waters of the diagenetic carbonates had a calculated $\delta^{18} \mathrm{O}_{\mathrm{SMOW}}$ of -2 to $-1 \%$. Using this estimated signal for diagenetic waters (assuming it did not change with burial), temperatures needed to precipitate the most depleted calcite $\left(\delta^{18} \mathrm{O}_{\mathrm{PDB}}\right.$ value of $-13 \%$ ) range between 80 and $100^{\circ} \mathrm{C}$, which correspond to estimated burial depths of 1.5 to $2.0 \mathrm{~km}$. These values are minimal because the salinity of fluids generally increase with burial and the parent waters could have had a higher ratio from the start (see text). Thus simple heating due to burial in the presence of a high geothermal gradient can generate carbonates with the range of $\delta^{18} \mathrm{O}_{\mathrm{PDB}}$ values obtained.

Al-Aasm, I. and Veizer, J. 1986. Diagenetic stabilization of aragonite and Low-Mg calcite, II. Stable Isotopes in Rudists. Journal Sedimentary Petrology, 56, pp. 763-770.

Anderson, T.F. and Arthur, M.A. 1983. Stable isotopes of oxygen and carbon and their application to sedimentologic and paleoenvironmental problems. In Stable Isotopes in Sedimentary Rocks. SEPM, Short Course No. 10, Dallas 1983, Chapter 1 .

Bathurst, R.G.C. 1975. Carbonate sediments and their diagenesis. Developments in Sedimentology \#12, Second Edition, Elsevier, $658 \mathrm{p}$.

Belt, E.S. 1968. Post-Acadian rifts and related facies, eastern Canada. In Studies of Appalachian geology, Northern and Maritime. Edited by E. Zen et al. Wiley Interscience, New York, pp. 95-113.

Boenner, R.C. 1986. Salt and potash resources in Nova Scotia. Department of Mines and Energy, Bulletin No. 5, 346 p.

Bradley, D.C. 1982. Subsidence in Late Paleozoic basins in the Northern Appalachians. Tectonics, 1, pp. 107-123.

$\mathrm{CHI}_{\mathrm{H}}$ G. and SAVARD, M.M. 1995. A preliminary microthermometric 
study of the Sugar Camp, Yankee Line, and MacPhails Brook $\mathrm{Pb}-\mathrm{Zn}$ showings, Cape Breton Island, Nova Scotia. In Geological Survey of Canada, Current Research 1995-D, pp. 5358.

Chi, G., Savard, M.M., and Héroux, Y. 1995. Constraints from fluid inclusion data on the origin of the Jubilee $\mathrm{Zn}-\mathrm{Pb}$ deposit, Nova Scotia. Canadian Mineralogist, 33, pp. 709-721.

Choquette, P.W. and James, N.P. 1990. The deep burial environment. In Diagenesis. Edited by I.A. Morrow and D.W. Morrow. Geoscience Canada, Reprint Series \#4, pp. 13-34.

CraIG, H. 1965. The measurement of oxygen isotope paleotemperatures. In Stable isotopes in oceanographic studies and paleotemperatures. Edited by E. Tongiorgi. Consiglio Nazionale delle Ricerche, Laboratorio di Geologia Nucleare, Pisa, Italy, pp. 161-182.

Fallara, F. 1996. Evolution structurale, pétrographique et géochimie des carbonates, et modèle métallogénique de l'indice $\mathrm{Pb}$ Zn de Jubliee, Ile du Cap Breton, Nouvelle Ecosse. M.Sc. thesis, Institut National de Recherche Scientifique (Géoressources), 71 p. +6 appendices +1 color map.

Fallara, F., Savard, M.M., Lynch, G., and Paradis, S. 1994. Preliminary $\delta^{18} \mathrm{O}$ and $\delta^{13} \mathrm{C}$ results characterizing the pre-, syn- and post-ore fluids affecting the Macumber Formation at the Jubilee $\mathrm{Pb}-\mathrm{Zn}$ deposit, Cape Breton Island, Nova Scotia. Geological Survey of Canada, Current Research 1994-D, pp. 63-71.

Fowler, M.G., Hamblin, A.P., MacDonald, D.J., and McMahon, P.G. 1993. Geological occurrences and geochemistry of some oil shows in Nova Scotia. Bulletin of Canadian Petroleum Geology, 41, pp. 422-436.

Fralick, P.W. and Schenk, P.E. 1981. Molasse deposition and basin evolution in a wrench tectonic setting: The late Paleozoic eastern Cumberland basin, Maritime Canada. Geological Association of Canada, Special Paper 23, pp. 77-97.

Geldsetzer, H.H.J. 1977. The Windsor Group of Cape Breton Island, Nova Scotia. Report of Activities, Part A; Geological Survey of Canada, Paper 77-1A, pp. 425-428.

Gibling, M.R., Boehner, R.C., and Rust, B.R. 1987. The Sydney Basin of Atlantic Canada: an upper Palaeozoic strike-slip basin in a collisional setting. Canadian Society of Petroleum Geologists, Memoir 12, pp. 269-285.

GILES, P.S. 1981. Major transgressive-regressive cycles in the Middle to Late Visean rocks of Nova Scotia. Department of Mines and Energy, Nova Scotia, Paper 81-2, 27 p.

Hamblin, A.P. and Rust, B.R. 1989. Tectono-sedimentary analysis of alternate polarity half-graben basin-fill successions: Late Devonian-Early Carboniferous Horton Group, Cape Breton Island, Nova Scotia. Basin Research, 2, pp. 239-255.

Hein, F.J., Graves, M.C., and Ruffman, A. 1993. The Jubilee $\mathrm{Zn}-\mathrm{Pb}$ deposit, Nova Scotia: the role of synsedimentary faults. Geological Survey of Canada, Paper 91-9, pp. 49-69.

Héroux, Y., Chagnon, A., Saint-Antoine, P., and Savard, M.M. 1994. Organic matter and clay assemblages from the Gays River, Jubilee and Walton deposits. In Program and summaries, eighteenth review of activities of the Nova Scotia Department of Natural Resources, Mines and Minerals and Energy Branch, p. 55.

Howie, R.D. and BArss, M.S. 1975. Upper Paleozoic rocks of the Atlantic provinces, Gulf of St-Lawrence, and adjacent continental shelf. Geological Survey of Canada, Paper 74-30, pp. 35-50.

KELLEY, D.G. 1967. Baddeck and Whycocomagh map-areas. Memoir 351, Geological Survey of Canada, 65 p.

Lavoie, D. 1994. The early Carboniferous (Visean) Macumber and Pembroke Formations (Windsor Group), Nova Scotia: Lithologies and preliminary paleoenvironmental interpretations. In Geological Survey of Canada, Current Research 1994-D, pp. 79-88.

Lavoie, D. and Savard, M.M. 1995. The Early Carboniferous Macumber Formation of the Magdalen Basin, Nova Scotia: Back to the deep water microbial laminites. Geological Association of Canada, Victoria, Program with Abstracts, p. A56.

Lavoie, D., Sangster, D.F., Savard, M.M., and Fallara, F. 1995. Multiple brecchia events in the lower part of the Carboniferous Windsor Group, Nova Scotia. Atlantic Geology, 31, pp. 197-207.

Lister, G.S., Etheridge, M.A., and Symonds, P.A. 1991. Detachment models for the formation of passive continental margins. Tectonics, 10, pp. 1038-1064.

Lohmann, K.C. 1988. Geochemical patterns of meteoric diagenetic systems. In Paleokarst. Edited by N.P. James and P.W. Choquette. Springer-Verlag, pp. 58-80.

LohmanN, K.C. and WALKeR, J.C.G. 1989. The $\delta^{18} \mathrm{O}$ record of Phanerozoic abiotic marine calcite cements. Geophysical Research Letters, 16, pp. 319-322.

Lynch, G. and Giles, P. In press. The Ainslie detachment: a regional flat-lying Carboniferous extensional fault in the evaporitic Maritimes Basin, Nova Scotia, Canada. Canadian Journal of Earth Sciences, 33.

Lynch, G. and Tremblay, C. 1994. Late Devonian-Carboniferous detachment faulting and extensional tectonics in western Cape Breton Island, Nova Scotia. Tectonophysics, 238, pp. 55-69.

Mamet, B.L. 1970. Carbonate microfacies of the Windsor Group (Carboniferous), Nova Scotia and New Brunswick. Geological Survey of Canada, Paper 70-21, 66 p. +19 plates.

Paradis, S., Savard, M.M., and Fallara, F. 1993. Preliminary study on diagenesis and mineralization of the Jubilee $\mathrm{Pb}-\mathrm{Zn}$ deposit, Nova Scotia. Current Research, Paper 93-1D, Part D, pp. 111-119.

Popp, B., Anderson, T.F., and SAndberg, P.A. 1986. Brachiopods as indicators of original isotopic compositions in some $\mathrm{Pa}$ leozoic limestones. Geological Society of America Bulletin, 97, pp. 1262-1269.

SCHENK, P.E. 1967. The Macumber Formation of the Maritimes Provinces, Canada, a Mississipian analogue to recent strand-line carbonates of the Persian Gulf. Joumal of Sedimentary Petrology, 37, pp. 365-376.

-.-- 1992. A lacustrine origin for the basal Windsor/Codroy Groups (Carboniferous) of Atlantic Canada - Introducing Loch Macumber! Geological Association of Canada, Wolfville 1992, 17, p. A99.

Sheridan, R.E. and Drake, C.L. 1968. Seaward extension of the Canadian Appalachians. Canadian Journal of Earth Sciences, 5, pp. 337-374.

Smalley, P.C., Higgins, A.C., Howarth, R.J., Nicholson, H., Jones, C.E., Swinburne, N.H.M., and Bessa, J. 1994. Seawater Sr isotope variations through time: A procedure for constructing a reference curve and correlate marine sedimentary rocks. Geology, 22, pp. 431-434.

Tissot, B.P. and Welte, D.H. 1984. Petroleum formation and occurrence. Springer-Verlag, Berlin, Heidelberg, New York, Tokyo, 699 p.

Utting, J. 1987. Palynology of the Lower Carboniferous Windsor Group and Windsor-Canso boundary beds of Nova Scotia, and their equivalents in Quebec, New Brunswick and Newfoundland. Geological Survey of Canada Bulletin, 374. 
Utring, J. and Hamblin, A.P. 1991. Thermal maturity of the Lower Carboniferous Horton Group, Nova Scotia. International Journal of Coal Geology, 19, pp. 439-456.

VEIZER, J. 1983. Chemical diagenesis of carbonates: theory and application of trace element technique. In Stable isotopes in sedimentary geology. Society Economic Paleontologists Mineralogists, Short Course No.10, Chapter 3.
White, C.E., Barr, S.M., and Cambell, R.M. 1990. Petrology of the Creignish Hills Pluton, Cape Breton Island, Nova Scotia. Atlantic Geology, 26, pp. 109-123.

Editorial responsibility: P.S. Giles and G.L. Williams 